\title{
Quality of Health Care in the Adult Critical Care Units in Port Said Hospitals.
}

\author{
Prof. Eman Salman Taie; Assistant Prof. Mona Abdelsabour Hassan ; Dina Saad \\ Hassan \\ Professor of Nursing Administration - Faculty of Nursing - Helwan University; \\ Assistant Professor of Community and Family Health Nursing - Faculty of Nursing - \\ Port Said University; Nursing Specialist-Port Said Health Directorate
}

\begin{abstract}
Background: Quality management strives to create a positive, open, and honest culture that provides health care services judiciously. The quality process is designed to monitor and trend problems. Most quality measures consider the structure, process, and outcome standards as frameworks. Aim: the present study aimed to assess quality of health care in the adult critical care units as perceived by nurses and patients. Subjects and methods: A descriptive study was used with a sample of (70) nurse and (116) patient. The data were collected by using two tools; Nurses' perception questionnaire and Patients' perception questionnaire. Results: The study results revealed that a statistically significant difference was found between nurses' and patients' perception regarding the structure factor and process factors affecting quality of health care Conclusion: It was concluded that the process and structure factors were the most important factors as reported by nurses and patients, while the outcome factor was the lowest one as reported by nurses. Recommendation: Nursing administrators should be properly selected and prepared for their role as efficient leaders to be a source of empowerment for their staff and the nursing profession, Providing continuing supervision and evaluation of nurses for the detection of any deficit in their performance and correction of the weakness and patients must continuously asked or assessed for their opinion or perception regarding the quality of care.
\end{abstract}

Key words: Quality of health care-Nurses' perception-Patients' perception-Critical care unit. 


\section{INTRODUCTION}

The future emphasis for care to be delivered in the National Health Service (NHS) is focused on quality of patient care and patient safety. Defining and measuring the quality of nursing care, is to be developed as part of the quality metrics (indicators) to reflect issues of safety, effectiveness, patient experience, and compassion. Joint Commission on Accreditation of Health Care Organization (JCAHO) stated that quality is the degree to which patient care services increases the probability outcomes, given the current state of knowledge. The role of professional nurse in organizations is to assess, maintain, and develop nursing competencies that increase the probability of desired outcomes and reduce the probability of undesired outcomes (Kelly, Marques, Gillies \& Strock, 2013).

The word quality has many meanings: a degree of excellence, conformance with requirements, the totality of characteristics of an entity that bear on its ability to satisfy stated or implied needs, fitness for use, freedom from defects, and imperfections or contamination and delighting customers .Quality has always been a primary concern in the health care field. It determines how successfully to prevent and treat physical and mental illness which affect the well being of patient and his family. Quality is not the result of a task, regulation or committee, but it is the result of people's values, behaviors, and structures, which focused toward the common goals. Quality management is based on the philosophy that we should do things right the first time and always strive for improvement. Quality management involves everyone on the improvement team and encourages everyone to make contributions (Sohail. et al 2012).

Quality of nursing care can be measured by nursing standards. which divided in to three types: Structure, process and outcome standards. The structure standards include manpower, material resources like buildings, budget and equipments . the process standards include the performance of nurses, physicians and other professionals in management of patients. Outcome standards are the results of Care or intervention, and patients' satisfaction. So that structure, process and out came standards are affecting the quality of Care provided to the patients. (Clark, 2009). An integrated quality control system must focus on these certain factors, Standards of care 
in terms of structure, process, outcome and their interrelatedness must be determined to assure that the quality assurance program validity reflects the quality of patients' care. Due to evaluate the process of nursing care. Quality assurance personnel examine the interaction of nurses and patients. All of that may be done through direct observation or by interviewing nurses and patients. (Gillies, 2008).

Critical care unit is a clearly defined area within the hospital, in which experts' medical , nursing, and technical staff are provided with equipment for monitoring and immediate life-saving interventions, these grew in parallel with advances in invasive surgical and medical procedures. The foregoing means that, patients who are admitted to the aforementioned area are mostly characterized by life threatening health problems. They most probably present with signs of impending death perceived on their own, or through others' experience So quality of health care provided to patients in the critical care unit are very important than any other area . (Hopkinson, 2010). Nurses at all levels are playing an active role in evaluating the quality of health care, Nurses are the only consistent profession to be in constant 24-hour surveillance of patients in hospital. Ensuring adequate nurse numbers, improving access to education and competence is necessary to deliver quality of patients' care and safety their involvement leads to opportunities to work with colleagues in other professions, both to better articulate their respective contributions and to improve patient outcomes (John \& George 2012).

\section{Significance of the study}

Providing quality of health care services has significant relationship with patients' satisfaction, patients' retention, loyalty, costs, profitability service guarantees and growth of organization. (Sohail. et al 2004). However, the poor state of patients service in some public hospitals in Egypt has resulted in high turnover and weak morale among staff. also, making it difficult to guarantee 24-hour coverage resulting in problems with patients' care and increased cost of operations due to inefficiencies all of that Leading some patients to look for an alternative provider and to spread negative word of mouth which affects potential clients hence growth of the hospital (Tam, 2005). 


\section{AIM OF THE STUDY:}

The present study aims to Assess quality of health care in the adult critical care units in port said hospitals through:

1-Assess factors affecting the quality of nursing care as perceived by nurses in Port Said hospitals.

2-Assess factors affecting quality of nursing care in the adult critical care units as perceived by patients in Port Said hospitals.

3-Assess factors affecting quality of healthcare in the adult critical care units in Port Said hospitals.

\section{Research Questions:}

1-What is nurses' perception about factors affecting quality of health care in the adult critical care units in Port Said hospitals?

2-What is patients' perception about factors affecting quality of health care in the adult critical care units in Port Said hospitals?

3-What are factors affecting quality of health care in the adult critical care units in Port Said hospitals?

\section{SUBJECTS AND METHODS:}

\section{Research Design:}

A descriptive design was used for this study.

\section{Study Setting}

The study was conducted at adult critical care units in three selected hospitals, representing three different health care sectors in Port Said city as follows:

1. Port-Said General Hospital (Governmental sector) which was the largest governmental hospital in port said city.

2. El-Tadamon Hospital (Health insurance sector) which was the only health insurance hospital had A CCU. 
3. AL-Soliman Private Hospital (Private sector) which was the only one private hospital in port said city.

\section{Subjects:}

The subjects of this study consisted of two groups.

\section{First group: Staff Nurses:}

All staff nurses working at CCU in the pre-mentioned hospitals with a total number of (70) nurses, divided as follows: all nurses working at CCU were (24) nurses from Port Said general hospital, (28) nurses from AL Soliman hospital and (18) nurses from AL-Tadamon hospital.

\section{Inclusion criteria:}

The study included nurses with at least one year of experience in their current job, holding a bachelor degree and technical institute or diploma nurses who agreed to participate.

\section{The Exclusion Criteria:}

The trainee nursing staff members were excluded. (These are trainees nurses in the job orientation during the period of study) and Student nurses of any educational level.

\section{Second group: Patients.}

All available adult patients in the pre-mentioned setting, the number of patients is calculated to be as follow; from AL-Soliman hospital was (39) patients, Port said general hospital was (47) patients and from Al-Tadamon hospital was (30) patients.

\section{Inclusion criteria}

The study included patients who stay 5days or more in the selected hospitals 


\section{Exclusion criteria:}

Any patients who have a disturbance level of consciousness as (comatosed patients -patients with pre-hepatic coma - confused or disoriented patients) and Patients who are not able to talk as result of their critical condition.

\section{Tools of data collection}

Two tools were used in this study as follows:

\section{The first tool:}

\section{1- $\quad$ Nurses' perception questionnaire (N P Q): (Appendix I)}

The nurses' perception questionnaire was based on (Gad 2002). It is used to identify the perception of nurses, regarding the factors affecting the quality of nursing care. It consists of four parts:

\section{The first part:}

This part aims to collect data about personnel characteristics as (age, gender, level of education, type of ward and job characteristics of the nurses involved in the study.

\section{The second part:}

This part was dealing with the structure factors affecting the quality of nursing care in the different units in the pre-mentioned hospitals; it consists of (7) dimensions which are divided into (35) sub-items as follows: Rules and Regulation, Physical and financial resources, Human resources, Job related factors, Work environment, Support services and organizational climate.

\section{The third part:}

This part was concerned with the process factors affecting quality of nursing care in the pre-mentioned hospitals units. It consisted of (5) dimensions divided in to (18) sub- items as follows: Efficient provision of care, Developing of care plan, The implementation of care plan, Communicating with patients and Continuous evaluation of patients.

\section{The fourth part:}


This part was concerned with the outcome factors affecting quality of nursing care in the pre mentioned hospitals. It consists of (2) dimensions divided into (9) sub- items as follows: Factors related to staff and Factors related to patients.

Scoring System: nurses perception questionnaire items were scored 1, 2, 3 ,4and 5 for the response (non important totally, non important, to some extent, important and very important) respectively.

\section{The nurses perception score was considered:}

- $\quad$ Low if thescorewaslessthan60\%.

- $\quad$ Moderate if the score was from $60 \%$ to $74 \%$.

- $\quad$ High if the score was more than 74\%. (Schutzenhofer \& Musser 1994).

This tool was tested for its validity and reliability using r: Pearson coefficient, *:Statistically significant at $\mathrm{p} \leq 0.05$ and Cronbach's techniques which indicated that alpha for structure, process and outcome factors as follow: 0.92, 0.88 and 0.62.

\section{The second tool:}

\section{(Patients' perception Questionnaire PPQ) (Appendix II):}

The Patients' perception questionnaire was developed by Gad (2002). It is used to identify the perception of patients regarding the factors affecting quality of nursing care. It consists of three parts.

\section{The first part:}

This part includes data related to the personnel characteristics of patients such as (occupation, level of education, age, date of admission, and diagnosis).

\section{The second part:}

This part was dealing with the structure factors affecting quality of nursing care in the critical care unit; it consists of (5) dimensions divided into (14) sub- items as follows:

Rules and regulation, Physical and financial resources, Human resources, work environment and Support services. 


\section{The third part:}

This part was concerned with the process factors affecting quality of nursing care in the critical care unit. It consisted of (5) dimensions divided into (10) sub items as follows: Efficient provisions, Development of a care plan , Implementation of patient's plan ,Communication with patients and Continuous evaluation of patients' condition.

Scoring System: nurses perception questionnaire items were scored 1, 2, 3, 4 and 5 for the response (non important totally, non important, to some extent, important and very important) respectively.

\section{The nurses perception score was considered:}

- Low if the score was less than $60 \%$.

- Moderate if the score was from $60 \%$ to $74 \%$.

- High if the score was more than 74\%. (Schutzenhofer \& Musser,1994).

This tool was tested for its validity and reliability by using $r$ : Pearson coefficient, *: Statistically significant at $\mathrm{p} \leq 0.05$ and Cronbach's techniques which indicated that the alpha for structure and process factors were 0.80 and 0.78 .

\section{OPERATIONAL DESIGN:}

Operational design includes three stages namely; preparatory stage, pilot study and the field work.

\section{Preparatory Stage:}

During this stage, review of literature mainly related to quality of health care in the adult critical care units and its factors affecting of it was done. The intended tool of data collection, getting the preliminary approval of the medical director and matron of nursing service of the selected hospitals was also started at this stage. The operational design involves discussion of validity and reliability of tool.

\section{Pilot Study:}

A pilot study was carried out on a sample of $10 \%$ of the nurses (6) nurses and (11) patients and was chosen randomly before embarking on the data collection and they were not included in the study sample. The aim of this pilot study was to test the data 
collection tools clarity and applicability on the sample, to estimate the time needed to complete the data collection tools and finally to identify the possible obstacles or problems in data collection. Necessary modifications were done.

\section{Field Work:}

This stage includes collection of data, this collection was completed over a period of six months from the beginning of June till the end of December 2014, during the morning and afternoon shifts, before distributing the questionnaire sheet, clear instructions were given to every participant about the purpose of the study. The questionnaire sheets were distributed and collected on the same day. Each questionnaire sheet for nurses took about (20-30) minutes to be fulfilled. The researcher checked each questionnaire sheet after being completed by the participants to ensure the completion of all items. Interviewing patients involved in the present study in both hospital using a questionnaire sheets, immediately before patients discharge from critical care unit in the selected hospitals. Before the interview, the purpose of the study was explained to the patients, the interview was conducted in simple language, and each interview lasted for about (20-30) minutes.

\section{(III) ADMINISTRATIVE DESIGN:}

An official permit was taken from the dean of the faculty of Nursing in Port Said University to the nursing director of the previous mentioned hospital to ensure their cooperation and permission. Written approval was obtained to conduct the study after explaining the purpose and objectives of the study.

\section{Ethical Consideration:}

The aim of the study was explained to each participant either nurses or patients, to obtain their agreement and to be familiar with the importance of her participation and assure to them that the information obtained will be confidential and used only for the purpose of the study. A verbal consent was obtained from each participant in the study, after a clear and simple explanation of the purpose and importance of the study. Confidentiality, anonymity and the right to withdraw from the study at any time were guaranteed. 


\section{Statistical design:}

Data entry and statistical analysis were done using SPSS14.0 statistical software package. Data were presented using descriptive statistics in the form of frequencies and percentage for qualitative variables, and means and standard deviations for quantitative variables were compared using chi-square test. Quantitative continuous data were compared using student t-test for compare nurses' and patients' perception of the selected hospitals and Paired t-test for comparing nurses' and patients' perception in each hospital and Pearson correlation analysis was used for the assessment of the interrelationships among quantitative variables that were statistically significant when considered at $\mathrm{p}$-value $\leq 0.05$.

\section{RESULTS:}

Table (1): Presents comparison between nurses' personal and job characteristics in the selected hospitals, the results showed that less than three quarters of the studied nurses $(71.4 \%)$ were less than 30 years, their mean of age was $(27.21 \pm 4.48)$. Also, nearly half of them (42.9\%) had nursing diploma, nearly two fifths of them (41.4\%) had less than 5 years of experience, their mean years of experience was $(7.54 \pm 4.69)$. nearly three quarters $(68.6 \%)$ of them had worked less than ( 8) working hours/day, their mean of number of working hours/day was $(7.24 \pm 0.89)$, the majority of them (82.9) are responsible for 3:6 patients/shift and their mean number of patients/shift was ( $4.37 \pm 1.52)$.

Table (2): Reveals the level of studied nurses' perception regarding the important factors affecting quality of health care, this table reveals that all nurses in both port said general and Al- Soliman hospital(100\%)had a high level of nurses' perception regarding process factors affecting quality of health care, while (100\%)of studied nurses in port said general hospital had low level of perception regarding the outcome factors affecting quality of health care.

Table (3): Represents levels of nurses' perception regarding the (structure, process and outcome) factors affecting quality of health care in the selected hospitals.(Total $\mathrm{N}=70$ nurses).the table reveals that $(88.6 \%$ )of nurses had high perception level about structure factors. And also These results indicates that 
(89.6\%)of nurses had high perception level regarding process factors . on the other hand (92.9\%)of nurses had low perception level about outcome factors, Also the table revealed that there are no statistically significant differences between them.

Table (4): Represents level of studied patients' perception regarding the important factors affecting quality of health care in the CCU in the selected hospitals. This table showed that (90\%)of studied patients had high level of perception regarding process factors were detected in al-tadamon hospital and also (84.6\%)of studied patients had high level of perception regarding structure factors were detected in al- soliman hospital.

Table (5): Represents levels of Patients' perception regarding the important factors affecting quality of health care in the selected hospitals. This table reveals that (70.7\%)of patients had high perception level about structure factors , and also The results indicates that $(89.6 \%)$ of patients had high perception level regarding process factors .Also this table revealed that there are no statistically significant differences between them.

Figure (1): Reveals relationship between nurses' and patients' perception regarding the important factors affecting quality of health care in Port Said hospitals. A statistically significant difference were found in areas of structure factors as rules \& regulation $(\mathrm{p}=4.972 *)$, physical \&financial resources $\left(\mathrm{p}=5.655^{*}\right)$, work environment $\left(\mathrm{p}=4.077^{*}\right)$ and total structure factors $\left(\mathrm{p}=4.710^{*}\right)$.

Figure (2): Reveals relationship between nurses' and patients' perception regarding the important factors affecting quality of health care in Port Said hospitals. A statistically significant difference were found in areas of process factors in relation to developing of care plan $\left(\mathrm{p}=5.360^{*}\right)$, the implementation of patient plan $\left(\mathrm{p}=4.893^{*}\right)$, communicating with patients $\left(\mathrm{p}=4.868^{*}\right)$ and finally, the total process factors $(\mathrm{p}=3.419 *)$. 
Table (1): personal and job characteristics of the studied nurses in the three studied hospitals.

\begin{tabular}{|c|c|c|c|c|c|c|c|c|}
\hline \multirow{3}{*}{$\begin{array}{c}\text { Nurses' Personal } \\
\text { \& } \\
\text { Job Characteristics }\end{array}$} & \multicolumn{6}{|c|}{ Hospitals } & \multirow{2}{*}{\multicolumn{2}{|c|}{$\begin{array}{c}\text { Total } \\
(\mathbf{n}=\mathbf{7 0})\end{array}$}} \\
\hline & \multicolumn{2}{|c|}{$\begin{array}{l}\text { Al-Tadamon } \\
\quad(\mathbf{n}=\mathbf{1 8})\end{array}$} & \multicolumn{2}{|c|}{$\begin{array}{c}\text { Port Said } \\
\text { General } \\
(\mathbf{n}=\mathbf{2 4})\end{array}$} & \multicolumn{2}{|c|}{$\begin{array}{l}\text { Al-Soliman } \\
\quad(n=28)\end{array}$} & & \\
\hline & No. & $\%$ & No. & $\%$ & No. & $\%$ & No. & $\%$ \\
\hline Age & & & & & & & & \\
\hline$<30$ & 13 & 72.2 & 11 & 45.8 & 26 & 92.9 & 50 & 71.4 \\
\hline$\geq 30$ & 5 & 27.8 & 13 & 54.2 & 2 & 7.1 & 20 & 28.6 \\
\hline Min. - Max & \multicolumn{2}{|c|}{$24.0-35.0$} & \multicolumn{2}{|c|}{$21.0-40.0$} & \multicolumn{2}{|c|}{$16.0-43.0$} & \multicolumn{2}{|c|}{$16.0-43.0$} \\
\hline Mean \pm SD & \multicolumn{2}{|c|}{$27.78 \pm 2.71$} & \multicolumn{2}{|c|}{$28.71 \pm 4.69$} & \multicolumn{2}{|c|}{$25.57 \pm 4.79$} & \multicolumn{2}{|c|}{$27.21 \pm 4.48$} \\
\hline $\mathbf{F}(\mathbf{p})$ & \multicolumn{6}{|c|}{$3.617^{*}\left(0.032^{*}\right)$} & & \\
\hline \multicolumn{9}{|l|}{ Qualification } \\
\hline Nursing diploma & 9 & 50.0 & 12 & 50.0 & 9 & 32.1 & 30 & 42.9 \\
\hline Technical nursing institute & 6 & 33.3 & 4 & 16.7 & 9 & 32.4 & 19 & 27.1 \\
\hline Bachelor of Nursing & 3 & 16.7 & 8 & 33.3 & 10 & 35.7 & 21 & 30.0 \\
\hline$\square^{\square}\left({ }^{\mathbf{M C}} \mathbf{p}\right)$ & \multicolumn{6}{|c|}{$4.193(0.402)$} & & \\
\hline \multicolumn{9}{|l|}{ Years of experience } \\
\hline$<5$ & 7 & 38.9 & 6 & 25.0 & 16 & 57.1 & 29 & 41.4 \\
\hline $5-10$ & 10 & 55.6 & 10 & 41.7 & 5 & 17.9 & 25 & 35.7 \\
\hline$>10$ & 1 & 5.6 & 8 & 33.3 & 7 & 25.0 & 16 & 22.9 \\
\hline Min. - Max & \multicolumn{2}{|c|}{$3.0-15.0$} & \multicolumn{2}{|c|}{$2.0-17.0$} & \multicolumn{2}{|c|}{$2.0-24.0$} & \multicolumn{2}{|c|}{$2.0-24.0$} \\
\hline Mean \pm SD & \multicolumn{2}{|c|}{$7.11 \pm 3.45$} & \multicolumn{2}{|c|}{$8.96 \pm 4.65$} & \multicolumn{2}{|c|}{$6.61 \pm 5.25$} & \multicolumn{2}{|c|}{$7.54 \pm 4.69$} \\
\hline $\mathbf{F}(\mathbf{p})$ & \multicolumn{6}{|c|}{$1.763(0.179)$} & & \\
\hline \multicolumn{9}{|l|}{ Number of working Hours } \\
\hline$<8$ & 17 & 94.4 & 19 & 79.2 & 12 & 42.9 & 48 & 68.6 \\
\hline$\geq 8$ & 1 & 5.6 & 5 & 20.8 & 16 & 57.1 & 22 & 31.4 \\
\hline Min. - Max & & & & 12.0 & & 8.0 & & 2.0 \\
\hline Mean \pm SD & 7.0 & 0.24 & & 1.27 & & 0.74 & & .89 \\
\hline $\mathbf{F}(\mathbf{p})$ & & & 1.095 & $341)$ & & & & \\
\hline Number of patients/shift & & & & & & & & \\
\hline$<3$ & 0 & 0.0 & 0 & 0.0 & 3 & 10.7 & 3 & 4.3 \\
\hline $3-6$ & 18 & 100.0 & 19 & 79.2 & 21 & 75.0 & 58 & 82.9 \\
\hline $7-10$ & 0 & 0.0 & 5 & 20.8 & 4 & 14.3 & 9 & 12.9 \\
\hline Min. - Max & & & & 8.0 & & 0.0 & & 0.0 \\
\hline Mean \pm SD & 3.6 & 0.49 & & 1.40 & & 1.89 & & .52 \\
\hline $\mathbf{F}(\mathbf{p})$ & & & $.243^{*}$ & $\left..045^{*}\right)$ & & & & \\
\hline
\end{tabular}

$\chi^{2}$ : Chi square test

F: F test (ANOVA)
MC: Monte Carlo test

$*$ : Statistically significant at $\mathbf{p} \leq \mathbf{0 . 0 5}$ 
Table (2): Level of the studied nurses' perception regarding the important factors affecting quality of health care in the CCU in the selected hospitals.

\begin{tabular}{|c|c|c|c|c|c|c|c|c|c|c|c|c|c|c|c|c|c|c|}
\hline \multirow{3}{*}{$\begin{array}{l}\text { Nurses' perception regarding the } \\
\text { important factors }\end{array}$} & \multicolumn{6}{|c|}{ AlTadamon(n=18) } & \multicolumn{6}{|c|}{ Port said ( $(n=24)$} & \multicolumn{6}{|c|}{ Al soliman $(\mathrm{n}=28)$} \\
\hline & \multicolumn{2}{|c|}{$\begin{array}{l}\text { Low } \\
600 \%\end{array}$} & \multicolumn{2}{|c|}{$\begin{array}{l}\text { Moderate } \\
60-74 \%\end{array}$} & \multicolumn{2}{|c|}{$\begin{array}{l}\text { High } \\
>74 \%\end{array}$} & \multicolumn{2}{|c|}{$\begin{array}{l}\text { Low } \\
<60 \%\end{array}$} & \multicolumn{2}{|c|}{$\begin{array}{l}\text { Moderate } \\
60-74 \%\end{array}$} & \multicolumn{2}{|c|}{$\begin{array}{l}\text { High } \\
>74 \%\end{array}$} & \multicolumn{2}{|c|}{$\begin{array}{l}\text { Lorr } \\
<60 \%\end{array}$} & \multicolumn{2}{|c|}{$\begin{array}{l}\text { Moderate } \\
60-74 \%\end{array}$} & \multicolumn{2}{|c|}{$\begin{array}{l}\text { High } \\
>74 \%\end{array}$} \\
\hline & $\mathrm{N}_{0 .}$ & $\%$ & $\mathrm{~N}_{0}$ & $\%$ & No. & $\%$ & $\mathrm{~N}_{0}$ & $\%$ & $\mathrm{~N}_{0 .}$ & $\%$ & $N_{0}$ & $\%$ & No. & $\%$ & $\mathrm{~N}_{0}$ & $\%$ & No. & $\%$ \\
\hline Structure factors & & & & & & & & & & & & & & & & & & \\
\hline Rules and Regulation & 6 & 33.3 & 4 & 22.2 & 8 & 44.4 & 0 & 0.0 & 1 & 4.2 & 23 & 95.8 & 0 & 0.0 & 1 & 3.6 & 27 & 96.4 \\
\hline Physical and fimancial resources & 0 & 0.0 & 1 & 5.6 & 17 & 94.4 & 1 & 4.2 & 0 & 0.0 & 23 & 95.8 & 0 & 0.0 & 0 & 0.0 & 28 & 100.0 \\
\hline Human resources & 1 & 5.6 & 6 & 33.3 & 11 & 61.1 & 0 & 0.0 & 2 & 8.3 & 22 & 91.7 & 0 & 0.0 & 5 & 17.9 & 23 & 82.1 \\
\hline Job related factors & 0 & 0.0 & 1 & 5.6 & 17 & 94.4 & 1 & 4.2 & 1 & 4.2 & 22 & 91.7 & 1 & 3.6 & 2 & 7.1 & 25 & 89.3 \\
\hline Patient enrironment & 2 & 11.1 & 3 & 16.7 & 13 & 72.2 & 0 & 0.0 & 2 & 8.3 & 22 & 91.7 & 0 & 0.0 & 3 & 10.7 & 25 & 89.3 \\
\hline Support services & 2 & 11.1 & 2 & 11.1 & 14 & 77.8 & 2 & 8.3 & 3 & 12.5 & 19 & 79.2 & 2 & 7.1 & 4 & 14.3 & 22 & 78.6 \\
\hline Organizational climate & 0 & 0.0 & 0 & 0.0 & 18 & 100.0 & 1 & 4.2 & 1 & 4.2 & 22 & 91.7 & 0 & 0.0 & 1 & 3.6 & 27 & 96.4 \\
\hline Orerall & 0 & 0.0 & 6 & 33,3 & 12 & 66.7 & 0 & 0.0 & 1 & 4.2 & 23 & 95.8 & 0 & 0.0 & l & 3.6 & 27 & 96.4 \\
\hline Process factors & & & & & & & & & & & & & & & & & & \\
\hline Efficient orision of care & 0 & 0.0 & 1 & 5.6 & 17 & 94.4 & 0 & 0.0 & 0 & 0.0 & 24 & 100.0 & 0 & 0.0 & 1 & 3.6 & 27 & 96.4 \\
\hline Developing care plan & 0 & 0.0 & 0 & 0.0 & 18 & 100.0 & 1 & 4.2 & 3 & 12.5 & 20 & 83.3 & 1 & 3.6 & 2 & 7.1 & 25 & 89.3 \\
\hline The implementation of care plan & 0 & 0. & 0 & 0.0 & 18 & 100.0 & 0 & 0.0 & 1 & 4.2 & 23 & 95.8 & 1 & 3.6 & 4 & 14.3 & 23 & 82.1 \\
\hline Communicating with patient & 1 & 5.6 & 0 & 0.0 & 17 & 94.4 & 0 & 0.0 & 1 & 4.2 & 23 & 95.8 & 1 & 3.6 & 1 & 3.6 & 26 & 92.9 \\
\hline Continuous evaluation of patient & 1 & 5.6 & 1 & 5.6 & 16 & 88.9 & 0 & 0.0 & 3 & 12.5 & 21 & 87.5 & 0 & 0.0 & 0 & 0.0 & 28 & 100.0 \\
\hline Orerall & 0 & 0.0 & l & 5.6 & 17 & 94.4 & 0 & 0.0 & 0 & 0.0 & 24 & 100.0 & 0 & 0.0 & 0 & 0.0 & 28 & 100,0 \\
\hline Outcome factors & & & & & & & & & & & & & & & & & & \\
\hline Factors felated to staff & 0 & 0.0 & 0 & 0.0 & 18 & 100.0 & 2 & 8.3 & 0 & 0.0 & 22 & 91.7 & 4 & 14.3 & 1 & 3.6 & 23 & 82.1 \\
\hline Factors related to patient & 17 & 94.4 & 1 & 5.6 & 0 & 0.0 & 24 & 100.0 & 0 & 0.0 & 0 & 0.0 & 27 & 96.4 & 1 & 3.6 & 0 & 0.0 \\
\hline Orerall & 14 & $\begin{array}{ll}77.8 \\
\end{array}$ & 4 & 22.2 & 0 & 0.0 & 24 & 100.0 & 0 & 0.0 & 0 & 0.0 & 27 & 96.4 & l & 3.6 & 0 & 0.0 \\
\hline
\end{tabular}


Table (3): Nurses' perception level regarding the (structure, process and outcome) factors affecting quality of health care in the selected hospitals.(Total $\mathrm{N}=70$ nurses).

\begin{tabular}{|c|c|c|c|c|c|c|}
\hline \multirow{2}{*}{$\begin{array}{l}\text { Nurses' perception regarding the } \\
\text { Important factors }\end{array}$} & \multicolumn{2}{|c|}{$\begin{array}{c}\text { Low } \\
<60 \%\end{array}$} & \multicolumn{2}{|c|}{$\begin{array}{l}\text { Moderate } \\
60-74 \%\end{array}$} & \multicolumn{2}{|c|}{$\begin{array}{l}\text { High } \\
>74 \%\end{array}$} \\
\hline & No. & $\%$ & No. & $\%$ & No. & $\%$ \\
\hline \multicolumn{7}{|l|}{ Structure factors } \\
\hline Rules and Regulation & 6 & 8.6 & 6 & 8.6 & 58 & 82.9 \\
\hline Physical and financial resources & 1 & 1.4 & 1 & 1.4 & 68 & 97.1 \\
\hline Human resources & 1 & 1.4 & 13 & 18.6 & 56 & 80.0 \\
\hline Job related factors & 2 & 2.9 & 4 & 5.7 & 64 & 91.4 \\
\hline Work environment & 2 & 2.9 & 8 & 11.4 & 60 & 85.7 \\
\hline Support services & 6 & 8.6 & 9 & 12.9 & 55 & 78.6 \\
\hline Organizational climate & 1 & 1.4 & 2 & 2.9 & 67 & 95.7 \\
\hline Overall & $\mathbf{0}$ & $\mathbf{0 . 0}$ & 8 & 11.4 & 62 & 88.6 \\
\hline \multicolumn{7}{|l|}{ Process factor } \\
\hline Efficient provision of care & 0 & 0.0 & 2 & 2.9 & 68 & 97.1 \\
\hline Developing care plan & 2 & 2.9 & 5 & 7.1 & 63 & 90.0 \\
\hline The implementation of care plan & 1 & 1.4 & 5 & 7.1 & 64 & 91.4 \\
\hline Communicating with patient & 2 & 2.9 & 2 & 2.9 & 66 & 94.3 \\
\hline Continuous evaluation of patient & 1 & 1.4 & 4 & 5.7 & 65 & 92.9 \\
\hline Overall & $\mathbf{0}$ & $\mathbf{0 . 0}$ & 1 & 1.4 & 69 & 98.6 \\
\hline \multicolumn{7}{|l|}{ Outcome factors } \\
\hline Factors related to staff & 6 & 8.6 & 1 & 1.4 & 63 & 90.0 \\
\hline Factors related to patient & 68 & 97.1 & 2 & 2.9 & 0 & 0.0 \\
\hline Overall & 65 & 92.9 & 5 & 7.1 & $\mathbf{0}$ & $\mathbf{0 . 0}$ \\
\hline
\end{tabular}

High significant $<0.01 *$ 
Table (4): Level of the studied Patients' perception regarding the important factors affecting quality of health care in the CCU in the selected hospitals.

\begin{tabular}{|c|c|c|c|c|c|c|c|c|c|c|c|c|c|c|c|c|c|c|}
\hline \multirow{3}{*}{$\begin{array}{l}\text { Patients' perception } \\
\text { regarding the important } \\
\text { factors }\end{array}$} & \multicolumn{6}{|c|}{ Al Tadamon $(\mathrm{n}=30)$} & \multicolumn{6}{|c|}{ Port said $(n=47)$} & \multicolumn{6}{|c|}{ Al soliman $(n=39)$} \\
\hline & \multicolumn{2}{|c|}{$\begin{array}{l}\text { Low } \\
<60 \%\end{array}$} & \multicolumn{2}{|c|}{$\begin{array}{l}\text { Moderate } \\
60-74 \% \\
\end{array}$} & \multicolumn{2}{|c|}{$\begin{array}{l}\text { High } \\
>74 \%\end{array}$} & \multicolumn{2}{|c|}{$\begin{array}{l}\text { Low } \\
<60 \% \\
\end{array}$} & \multicolumn{2}{|c|}{$\begin{array}{l}\text { Moderate } \\
60-74 \%\end{array}$} & \multicolumn{2}{|c|}{$\begin{array}{l}\text { High } \\
>74 \%\end{array}$} & \multicolumn{2}{|c|}{$\begin{array}{l}\text { Low } \\
<60 \%\end{array}$} & \multicolumn{2}{|c|}{$\begin{array}{l}\text {. Noderate } \\
60-74 \% \\
\end{array}$} & \multicolumn{2}{|c|}{$\begin{array}{l}\text { High } \\
>74 \%\end{array}$} \\
\hline & No. & $\%$ & No. & $\%$ & No. & $\%$ & No. & $\%$ & No. & $\%$ & No. & $\%$ & No. & $\%$ & $\mathrm{~N}_{0}$. & $\%$ & No. & $\%$ \\
\hline ructure factors & & & & & & & & & & & & & & & & & & \\
\hline Rules and Regulation & 9 & 30.0 & 1 & 3.3 & 20 & 66.7 & 22 & 46.8 & 1 & 2.1 & 24 & 51.1 & 2 & 5.1 & 3 & 7.7 & 34 & 87.2 \\
\hline Physical and financial resources & 3 & 10.0 & 2 & 6.7 & 25 & 83.3 & 1 & 2.1 & 5 & 10.6 & 41 & 87.2 & 3 & 7.7 & 2 & 5.1 & 34 & 87.2 \\
\hline Human resources & 2 & 6.7 & 2 & 6.7 & 26 & 86.7 & 1 & 2.1 & 2 & 4.3 & 44 & 93.6 & 2 & 5.1 & 0 & 0.0 & 37 & 94.9 \\
\hline Patient environment & 5 & 16.7 & 6 & 20.0 & 19 & 63.3 & 10 & 21.3 & 17 & 36.2 & 20 & 42.6 & 3 & 7.7 & 5 & 12.8 & 31 & 79.5 \\
\hline Support services & 5 & 16.7 & 4 & 13.3 & 21 & 70.0 & 3 & 6.4 & 4 & 8.5 & 40 & 85.1 & 6 & 15.4 & 2 & 5.1 & 31 & 79.5 \\
\hline Overall & 3 & 10.0 & 6 & 20.0 & 21 & 70.0 & 4 & 8.5 & 15 & 31.9 & 28 & 59.6 & 3 & 7.7 & 3 & 7.7 & 33 & 84.6 \\
\hline Process factors & & & & & & & & & & & & & & & & & & \\
\hline Efficient provision of care & 1 & 3.3 & 0 & 0.0 & 29 & 96.7 & 0 & 0.0 & 0 & 0.0 & 47 & 100.0 & 3 & 7.7 & 2 & 5.1 & 34 & 87.2 \\
\hline Developing care plan & 4 & 13.3 & 0 & 0.0 & 26 & 86.7 & 23 & 48.9 & 0 & 0.0 & 24 & 51.1 & 5 & 12.8 & 0 & 0.0 & 34 & 87.2 \\
\hline $\begin{array}{l}\text { The implementation of care } \\
\text { plan }\end{array}$ & 9 & 30.0 & 0 & 0.0 & 21 & 70.0 & 12 & 25.5 & 0 & 0.0 & 35 & 74.5 & 3 & 7.7 & 0 & 0.0 & 36 & 92.3 \\
\hline Communicating with patient & 3 & 10.0 & 5 & 16.7 & 22 & 73.3 & 6 & 12.8 & 8 & 17.0 & 33 & 70.2 & 4 & 10.3 & 2 & 5.1 & 33 & 84.6 \\
\hline $\begin{array}{l}\text { Continuous evaluation of } \\
\text { patient }\end{array}$ & 2 & 6.7 & 0 & 0.0 & 28 & 93.3 & 0 & 0.0 & 0 & 0.0 & 47 & 100.0 & 4 & 10.3 & 0 & 0.0 & 35 & 89.7 \\
\hline Overall & 1 & 3.3 & 2 & 6.7 & 27 & 90.0 & 0 & 0.0 & 3 & 6.4 & 44 & 93.6 & 4 & 10.3 & 2 & 5.1 & 33 & 84.6 \\
\hline
\end{tabular}


Table (5): Patients' perception level regarding the (structure and process) factors affecting quality of health care in the selected hospitals. (Total $\mathrm{N}=116$ patients).

\begin{tabular}{||l|c|c|c|c|c|c||}
\hline \multirow{2}{*}{\begin{tabular}{c} 
Patients' perception regarding the \\
\multicolumn{1}{|c|}{ important factors }
\end{tabular}} & \multicolumn{2}{c|}{ Low } & \multicolumn{2}{c|}{ Moderate } & \multicolumn{2}{c||}{ High } \\
\cline { 2 - 7 } & No. & \% & No. & $\%$ & No. & \% \\
\hline Structure factors & 33 & 28.4 & 5 & 4.3 & 78 & 67.2 \\
Rules and Regulation & 7 & 6.0 & 9 & 7.8 & 100 & 86.2 \\
Physical and financial resources & 5 & 4.3 & 4 & 3.4 & 107 & 92.2 \\
Human resources & 18 & 15.5 & 28 & 24.1 & 70 & 60.3 \\
Patient environment & 14 & 12.1 & 10 & 8.6 & 92 & 79.3 \\
Support services & $\mathbf{1 0}$ & $\mathbf{8 . 6}$ & $\mathbf{2 4}$ & $\mathbf{2 0 . 7}$ & $\mathbf{8 2}$ & $\mathbf{7 0 . 7}$ \\
\hline Overall & & & & & & \\
Process factor & 4 & 3.4 & 2 & 1.7 & 110 & 94.8 \\
Efficient provision of care & 32 & 27.6 & 0 & 0.0 & 84 & 72.4 \\
Developing care plan & 24 & 20.7 & 0 & 0.0 & 92 & 79.3 \\
The implementation of care plan & 13 & 11.2 & 15 & 12.9 & 88 & 75.9 \\
Communicating with patient & 6 & 5.2 & 0 & 0.0 & 110 & 94.8 \\
Continuous evaluation of patient & $\mathbf{5}$ & $\mathbf{4 . 3}$ & $\mathbf{7}$ & $\mathbf{6 . 0}$ & $\mathbf{1 0 4}$ & $\mathbf{8 9 . 7}$ \\
\hline Overall & & & & & & \\
\hline
\end{tabular}

High significant $<0.01 *$ 


\section{FIG (1): Relation between nurses' and patient's perception regarding the structure factors affecting quality of the care in $\mathrm{CCU}$ in the selected hospitals}

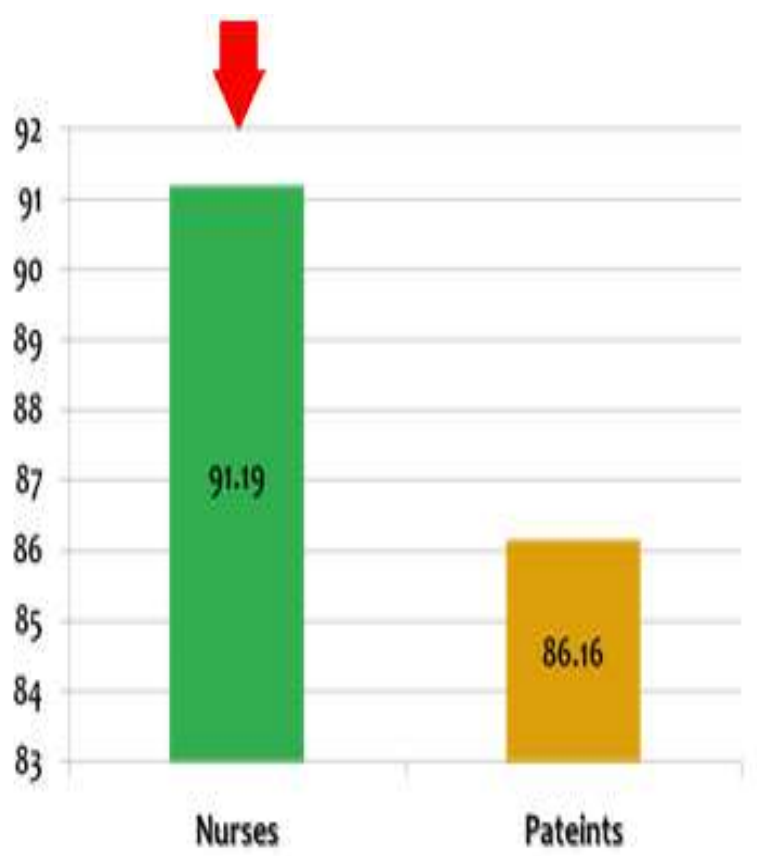

FIG (2): Relation between nurses' and patient's perception regarding the process factors affecting quality of the care in $\mathrm{CCU}$ in the selected hospitals

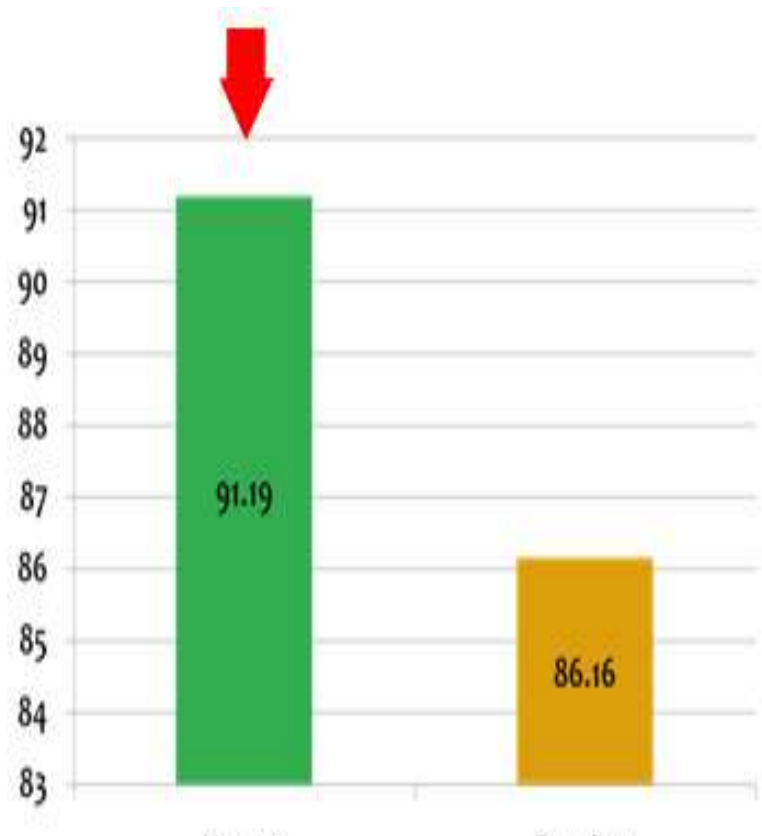

Nurses

Pateints

\section{DISCUSSION:}

The current study results showed that the majority of nurses considered the availability of physical and financial resources to be the most important areas in the structural factors affecting the quality of nursing care performance provided in the critical care units. This from the researcher's point of view may be due to the patients' feelings that nurses provided better care whenever they enjoy better financial satisfaction. These findings were confirmed by Gad. et al (2006) who clarified that the availability of supplies and equipment help the care providers to carry out any process. Moreover, if the care providers are financially satisfied they will improve their performance and decrease the rate of absenteeism and turnover which will improve the quality of nursing care.

According to the present study findings, the majority of studied nurses and patients agreed that the availability of both financial and emotional motives for working in the critical care units was the most important element in the structural factors affecting the quality of nursing care performance provided in the CCU. These findings were 
supported by Hamdy. et al (2007), who reported that the availability of supplies and equipment affected nurses' ability to provide high quality of nursing care performance and they added that, If equipment is available and provided with both competitive costs and quality, an organization will be more able to compete in the market place.

Results of this study revealed that the majority of studied nurses and patients agreed that good work climate is very important structural factors that affect the quality of nursing care performance provided in CCU. These findings were consistent with Tillman, Salyer, Corley \&Mark (2009) who said that the work environment has an impact upon nurses' performance, and who further stated that the critical care environment was defined by these characteristics.

The present study findings indicated that the majority of studied nurses and more than three quarters of patients were less concerned with the supporting services as a structural factors affecting quality of nursing care. These results were in contradiction with Galvin, \&Chassin, (2008) who stated that the collaboration among services improves the quality of care, increases patient satisfaction and reduces cost by decreasing length of stay. They added that, there is no health care professional who could deliver high quality care alone.

The current study results revealed that all nurses and the majority of patients agreed that the presence of good communication between the nurses and patients is a very important process factor that can affect the quality of nursing care in the critical care unit. These findings were supported by Adams, Bond, \&Arber (2008) who clarified that nurses do not work in isolation but in conjunction with other nurses ,other professions and patients. The previous findings are also consistent with Abd El-Fatah, (2008) who found that there was a correlation between the professional working relationship and the quality of nursing care in the critical care unit, good patient care requires that nurses and physicians work together in cooperation and respect. furthermore the nursing care quality level provided by participants in the critical care units is affected by the professional working relationship, unit's leadership, and nurses influence. These findings were also agree with Saad, \& durgahee, (2010) who stated that the Colleagues' 
relationships have been shown to influence the work of nurses and physicians. Also relationship with the managers and participation within the organization has a great impact on the quality of nursing care performance.

Results of the present study showed that the majority of nurses and more than three quarters of patients agreed that it is important to provide opportunities for promoting the knowledge of health team members including physicians, head nurses and nurses through training, seminars and conferences as very important factors affecting quality of nursing care .These results were supported by Durgahee, (2010) who reported that continued learning is the key for providing and maintaining a high level of service. Furthermore, he said that each nurse is responsible of improving professional knowledge, competence and skills.

The previous mentioned findings of the present study revealed that the majority of nurses and patients agreed that the efficient provision of care affects the quality of nursing care provided in the critical care unit. These findings were supported by Saad, (2007) who suggested that the presence of an adequate number of nurses and physicians is important. He further stated that the nurse should have the ability give the due care to each patient and to provide him or her with all the pieces of information they want.

The current study findings showed that all nurses and patients reported their concern with efficient provision of care which is considered the most important process factors that affect the quality of nursing care provided in CCU. These results were agree with $\mathbf{G a d}$, (2006) who found the same results. This from the researcher's point of view due to the fact that, efficiency of care is the corner stone of patient's desired outcome .

Findings of the present study revealed that the majority of nurses and patients agreed that meeting patient's physical needs is the most important factor affecting the quality of nursing care in CCU. These findings were supported by Mohamed (2008), 
who concluded that the first priority need perceived by patients and nurses was the physical needs and the second needs was the psychological needs. These findings were inconsistent with Aly, Hall, Dorman, Jenning, \& Muhlenkamp, (2009), who found that nurses and patients perceived psychological care as more important than physical care and patients give high priority to the psychological care and low priority to the physical one.

The present study results revealed the majority of nurses and near to one quarter of patients were less concerned with the defined outcome factors which include; mortality rate, complication rate, infection rate, readmission rate and patient satisfaction, these study results were supported by $\mathbf{G a d}$, (2006), who identified the same outcome factors. While de- emphasize on previous outcome factors contradicting with the Joint Commission on Accreditation of Health Care (2012). Also Rowland \& Rowland, (2007) who stated that the mortality and morbidity rates are performance indicators that can be used for measuring quality of care. These findings were on the same line Sullivan, (2009), and the Intensive Care Society in(2010), which clarified that continuous training of staff would be associated with more reduction of mortality and morbidity and improvement of efficiency and quality of care.

\section{CONCLUSION:}

In the light of the main study finding, it was concluded that nearly all of nurses had a high level of perception regarding process and structure, While the majority of nurses had a low level of perception regarding the outcome factors affecting quality of health care. And also the majority of patients had a high level of perception to process and structure factors affecting quality of health care in the CCU. finally A statistically significant differences were detected in all areas of nurses perceptions in relation to structure, process and outcome factors, Finally, there was a statistically significant association between nurses' and patients' perceptions regarding the important factors affecting quality of health care. 


\section{RECOMMENDATIONS:-}

Based on the findings of the present study, the following recommendations were suggested:

Nursing administrators should be properly selected and prepared for their role as efficient leaders to be a source of empowerment for their staff and the nursing profession.

$>$ Providing continuing supervision and evaluation of nurses for the detection of any deficit in their performance and correction of the weakness.

Providing continuous in service training programs and quality improvement programs for nurses.

Hospital management must explain all rules and regulations to the patients inside and outside the critical care unit.

Patients must be continuously asked or assessed for their opinion or perception regarding the quality of care.

Further studies are needed in different issues related to quality of nursing care to help in solving many problems related to this field and improve the quality services delivered .

\section{REFERENCES:}

Abd El-Fatah, M. (2008): "Impact of Organizational Features of Environment on Quality of Nursing Care and Nurses Commitment in the Critical Care Units in the Selected Hospitals within Cairo Governorate”. Unpublished Doctorate Thesis submitted to the Faculty of Nursing, Cairo University. P32-37, 133-153.

Adam K., and Osborne M. (2007) "Critical Care Nursing: Science and Practice" 1 st ed. Oxford Company. Toronto. P 1-13.

Adams A., Bond S., and Arber S. (2008): "Development and Validation of Scales to Measure Organizational Features of Acute Hospital Wards". International Journal of Nursing Studies, 32 (6): P 612-627.

Alanwar, H.M. (2012): Factors Associated with Nurses' Readiness for Change at Alexandria Main University Hospital. UnPublished Doctoral Dissertation. Faculty of Nursing ,Alexandria UniversitityP89-100. 
Aly, A. M. (2008): "Rates and Causes of Turnover among Nurses in Selected Hospitals in Cairo". Unpublished Master Thesis submitted to Faculty of Nursing, Cairo University. P89-111.

Aly, S. H. (2007): "Patients versus Nurses Perceptions of Important Aspects of Post Operative Nursing Care in Two Different Health Care Sectors". Unpublished Master Thesis submitted to the Faculty of Nursing, Cairo University. P5-24, 57-69.

Bonds, S. and Thomas, L.. (2007): "Measuring Patient Satisfaction with Nursing Care". Mosby, USA P 17, 36, 52.

Ball C, Mc Elligot M. (2008). Realizing the Potential of Critical Care Nurses: An exploration of the factors that affect and comprise the nursing contribution to the recovery of critically ill patients. Intensive and Critical Care Nursing. 19(4) P 226238.

Beckman U, Baldwin I, Hart GK. (2006) An Australian Incident Monitoring Study in Intensive Care: AIMS - ICU. An Analysis of the 1st Year Reporting. Anesthesia and Intensive Care; 24(3) P321-329.

Badran, S. (2007): "Thinking about Quality in Health Care". The $2^{\text {nd }}$ International Nursing Conference, Quality in Health Care: Administration and Nursing, Cairo, Egypt.P 19,42,106.

Caroly J., and Bessiel L.. (1996): "Leadership Roles and Management Functions in Nursing" $2^{\text {nd }}$ ed. Lippincott, USA. P 381-395.

Clark, J. and Copcutt, L. (1997): "Management for Nurses and Health Care Professionals". Churchill Livingstone, England. $4^{\text {th }}$ ed P 211, P 221-223.

Dean-Bear, S. (1994): "Standard and Guidelines, How Do They Assure Quality: Current issues in Nursing". $4^{\text {th }}$ ed. Mosby, St.Louis P 316-320.

Daft M., and Richard L.. (2011): "Management". The Drydelen Press International Edition, USA $.2^{\text {nd }}$ ed , P504-509. 
Dale, B. and Bunney, H. (2009): "Total Quality Management Blueprint Blackwell Business". Oxford Company, Oxford. $3^{\text {rd }}$ ed, P 4, 132, 259.

Department of Health (2009) Same Sex Accomodation in Practice: Critical Care Settings Pp 5,20 http://www.dh.gov.uk/en/Healthcare/

Samesexaccommodation/SSAinpractice/ DH_099083 (accessed 2/08/2009)

Durgahee, T. (2010): “Directions in Post-Basic Education”. Jornal of Senior Nurses 10 (7): Pp15-20.

Eggland, E. (2006): "Nursing Documentation Resources Guide". Pittsburg, Aspen. $2^{\text {nd }}$ ed, P254-259.

Gad, R. (2006): "Quality Care as Perceived by Nurses, Physicians, and Health Care Consumers". Unpublished Master, Thesis submitted to the Faculty of Nursing, Ain Shams University. P5-113.

Galvin, R. and Chassin, M. (2008): "The Urgent Need to Improve Health Care Quality”. JONA, 22 (12),P 10:15.

Gillies, A. (2008): "Nursing Management a System Approach". $3^{\text {rd }}$ ed. W.B. Saunders Company, London. P 535-536, 543.

Hall, J. and Dorman, M. (1999): "What Patients Like about Their Medical Care and How They Are Asked a Meta Analysis of the Satisfaction Literature". Soc Sci Med, 27 (2): P 935-939.

Hamdy, O. (2009): "Factors Associated with Employment and Conditions of Work of Nursing Personnel in Egypt". Tanta Med. Journal, 5 (3): P63-71.

Hopkinson, J. (2008): “Critical Care Nursing" 1 st ed. Oxford Company, Toronto. P118.

Hoyle, D. (2007): “QS-9000 Quality Systems Hand Book”. Butter worth Heinemann, $3^{\text {rd }}$ rd. P $5,9,11$.

Jennings, B. and Muhlenkamp, A. (2008): "Systemic Misperception: Oncology Patients' Self Reported Affective States and Their Care Givers' Perception”. Mosby, Yearbook USA. $5^{\text {th }}$ ed, P 485-489. 
John, D. and George, S. (2008): "Surgery A problem Solving Approach". $2^{\text {nd }}$ ed. Mosby, Yearbook USA. P 534.

Kelly, K. (2009): "Nursing Staff Development". $2^{\text {nd }}$ ed. Lippincott Company, Philadelphia. P 279.

Kelly, K. (2010): "Clinical and Nursing Staff Development Current Competence, Future Focus". $2^{\text {nd }}$ ed. Lippincott Roven Publisher. P 306-308.

Marquis, B and Huston, C (2010): "Leadership Roles and Management Functions in Nursing Theory and Application $2^{\text {nd }}$ ed. Lippincott, USA. P 384-387, P 392-394.

Marquis, B. and Huston, C. (2007): "Management Decision Making for Nurses" $2^{\text {nd }}$ ed. Lippincott USA. P 333:340.

McCloskey, B. (2008): "Fundamentals of Contemporary Nursing Practice". $3^{\text {rd }}$ ed , W.B. Saunders company, London. P 241-245.

Mohamed, N. (2009): "Nurses versus Patient's Perception Regards Patients Needs in Surgical Wards at Cairo University Hospitals". Unpublished Master, Thesis submitted to the Faculty of Nursing, Cairo University. P 51-60.

Mohamed, S. A. (2008): "Relationship between Job Satisfaction and Absenteeism among Nurses". Unpublished Master, Thesis submitted to the Faculty of Nursing, Ain Shams University. P64-120.

Mohamed, S. H. (2009): "Relationship between Nurses' Job Satisfaction and Patients' Satisfaction" Unpublished Master, Thesis submitted to the Faculty of Nursing, Ain Shams University. P40-67.

Peters, D. (2010): "Performance Improvement through Quality Improvement Teamwork": JONA, 24 (12) P 20.

Pilcher T. (2009). Collaboration and teamwork in critical care. Nursing in Critical Care; 14 (2), P 6:45.

Rowland, H. and Rowland, B. (2007,2008): "Nursing Administration Handbook". $4^{\text {th }}$ ed. Aspen Publishers Maryland P 406:410. 
Saad, N. (2008): "Developing Nursing Care Standards for Stroke Patients". Unpublished Doctorate, Thesis submitted to the Faculty of Nursing, Ain Shams University. P 75-140.

Salyer, D. (2008): "Essentials of Nursing Management Quality Assurance".. Macmillan Education, Hong Kong. $2^{\text {nd }}$ ed, P 1, 3, 37, 54.

Schutzenhofer \& Musser(1994): A management tool for achieving success: journal of advanced nursing (13),P.511-541.

Starrk, M. (2008): “Operations Management: A System Approach”. Boyed, and Fraser Company, London. P83.

Sohail, P . (2012): “Approaches to Nursing Standard". Aspen Publication, Maryland. $3^{\text {rd }}$ ed ,P 11:15.

Sullivan, E. and Decker, P. (2007): "Effective Leadership and Management in Nursing". Addison Wesley, $4^{\text {th }}$ ed, USA. P128:137, p 499.

Tam L. (2005): Social Organization Employee's Job Satisfaction in China Based on Multi-level Factor Analysis Method International Journal of u- and e- Service, Science and Technology Vol.8, No.2 (2015), p81-90.

Tillman, H. Salyer, J. Corley, M. and Mark, B. (2007): "Environmental Turbulence Staff Nurses Perspectives”. JONA, 27 (11): P15-22. 


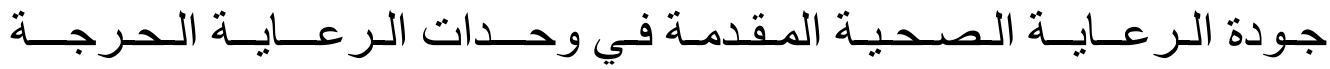

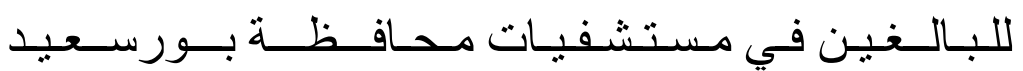

\author{
أ.د. إيـــان سـالـــان طــايع ، أ.م.د. مني عبد الصبور حسن ، دينا سعد حسن \\ أستاذ إدرة التصريض ورئبس قسم الإدرة- كلية التصريض - جامعة حلوان ، أستاذ مساعد تصريض صحة الأسرة

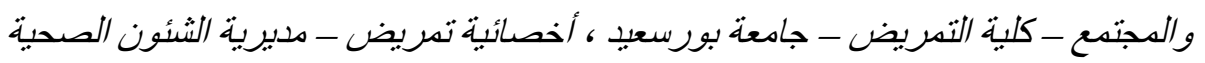

\section{الخلاصة}

الجودة هي إرضاء المريض و ذويه و هذا هو الهدف الأول لتقديم الرعاية التمريضية. نركز إدارة الجودة على منع حدوث أي مشاكل في تقديم الرعاية الصحية أو أثناء تقديمهاو من أهم أركان تقديم رعاية صحية ذات جودة عالية هو مهار ات كل من يقوم بتقديم هذه الرعاية. إن أكثر وسائل قياس جودة الرعاية الصحية منضمنة في نطاق ثلاث معايير مرتبطة ببعضها البعض وهم المعيار البنائي(الهيكلي)، المعيار العملي و المعيار التحصيلي

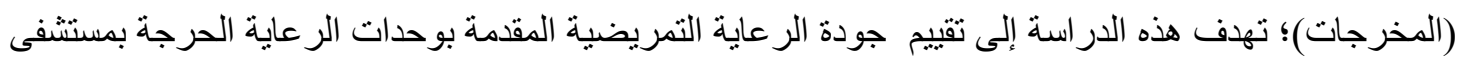
بورسعيد العام و مستشفى ال سليمان ومستشفى التضامن من خلال الممرضات والمرضى ـ تم إجراء هذه الدراسة في وحدات الرعاية الحرجة بالمستشفيات المختارة التى اثتملت على 70 ممرضة و116مريض ـ تم استخدام إستمارة إستبيان لجمع البيانات من الممرضات و إستمارة مقابلة شخصية لجمع البيانات من المرضى. اسفرت نتائج البحث عن موافقة كلآ من المررضات و المرضى على أن العوامل الخاصة بالمستوى العملى إلى و الهيكلى هما أهم العوامل المؤثرة على جودة الرعاية الصحية بوحدات الرعاية الحرجة بالآماكن المختارة. بينما كان المستوى التحصيلى أقل العو امل المؤثرة على جودة الرعاية التمريضية اما الخلاصة فهى وجود فروق ذات

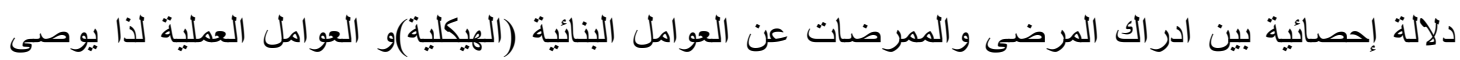
بضرورة عمل تقييم أو استطلاع لرأى المرضى عن جودة الرعاية الصحية المقدمة بوحدات الرعاية الحرجة

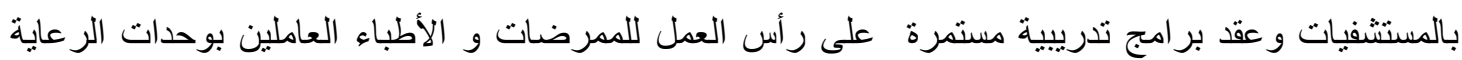

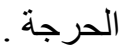

الكلمات المرشدة : جودة الرعاية الصحية- إدراك المدرضات - إدراك المرضى ـ وحدات الرعاية الحرجة 